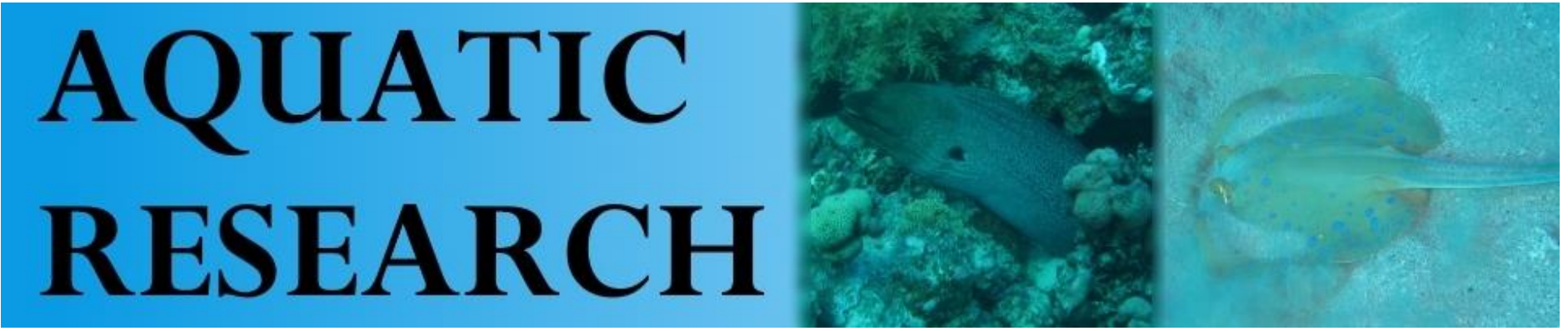

\title{
GENETIC DIVERSITY OF THE ENDEMIC SPECIES SHABBOUT (Arabibarbus grypus (HECKEL, 1843)) BASED ON PARTIAL CYTOCHROME B SEQUENCES OF MITOCHONDRIAL DNA
}

\author{
Arif Parmaksız $\stackrel{\text { id }}{\text { idio }}$, Özlem Şeker id
}

\section{Cite this article as:}

Parmaksı, A., Şeker, Ö. (2018). Genetic Diversity of the Endemic Species Shabbout (Arabibarbus grypus (Heckel, 1843)) Based on Partial Cytochrome B Sequences of Mitochondrial DNA. Aquatic Research, 1(3), 103-109. DOI: 10.3153/AR18011

Harran University, Faculty of Science and Art, Department of Biology, 63100, Şanlıurfa, Turkey

Submitted: 12.02 .2018

Accepted: 09.03.2018

Published online: 12.03 .2018

Correspondence:

Arif PARMAKSIZ

E-mail:

aprmksz@gmail.com

@C Copyright 2018 by ScientificWebJournals

Available online at

$\underline{\text { http://aquatres.scientificwebjournals.com }}$

\begin{abstract}
Arabibarbus grypus (Heckel, 1843), a species endemic in river systems of Euphrates and Tigris, is an economically important freshwater fish. In this study, the genetic diversity of Arabibarbus grypus populations was determined basen on partial cytochrome $b$ gene sequence of mtDNA. Totally 31 samples were collected from four localities and five polymorphic sites and five haplotypes were identified by carrying out mtDNA analysis. Mean haplotype $(\mathrm{Hd})$ and nucleotide diversity $(\pi)$ were calculated to be 0.348 and 0.00144 respectively. All values obtained following neutrality tests were found to be negative and statistically insignificant. Median joining network revealed that haplotype $\mathrm{H} 1$ was at the center of the network and was dominant. In the current survey, certain haplotypes $(\mathrm{H} 2, \mathrm{H} 4, \mathrm{H} 5)$ identified for mtDNA cytochrome $\mathrm{b}$ gene are the new results to the literature and presented a novel data set for genetic diversity of this species.
\end{abstract}

Keywords: Arabibarbus grypus, Cytochrome b, Genetic diversity, Euphrates River, Tigris River 


\section{Introduction}

Euphrates and Tigris Rivers are from important natural sources of fish diversity and fishing and also possess a considerable potential for meeting the need of food. Developed countries have started to conduct overall studies about species particularly with economic importance following the classification of fish in inland waters (Kaya, 2012). A majority of fish species inhabiting in basin of Euphrates and Tigris belongs to the family Cyprinidae. Because several species of this family are consumed for food, they posses economic importance (Parmaksiz et al., 2016). The fish preferred most by local people thanks to its delicious meat is Arabibarbus grypus (Shabbout). The fish distributed in Iran, Turkey, Syria, and Iraq is an endemic species thriving in river systems of Euphrates and Tigris (Nikpei, 1996; Abdoli, 2000; Khodadadi et al., 2016). Endemic fish species of fish are important in terms of ecological aspects and assumed as gene banks of an ecosystem (Khodadadi et al., 2016).

Some studies conducted on this species include age, growth, and reproductive traits (Oymak et al., 2008); heavy metal concentration in tissues (Oymak et al., 2009); determination of spermatological and hematologic characteristics (Dogu et al., 2014); the relationships between sagittal otolith size and length of the fish (Dusukcan et al., 2015); investigation for concentration of mercury in edible muscle tissues (Asefi and Zamani-Ahmadmahmoodi, 2015); the effects of probiotics derived from Lactobacillus species on immunologic parameters of Shabbout (Mohammadian et al., 2016); sperm morphology, motility and composition of seminal plasma parameters (Khodadadi et al., 2016); determination of genetic diversity utilizing from gene sequences of mtDNA COI (Parmaksiz et al., 2017).

Despite Oymak et al., (2009) stated in their study that Shabbout was abundant in the Euphrates, the number of individuals has decreased recently due to overhunting. It is crucial to know well about genetic diversity of this fish to ensure continuity of stocks and to obtain high yield from these stocks of the fish which is considered as an alternative to carp or trout for inland water fish farming (Gokcinar, 2010). There are several genetic markers based on DNA, however mtDNA studies have been made popular by developments of sequence analysis in recent years (Liu and Zhou, 2016). mtDNA, as an important and common molecular marker, has been used widey to estimate molecular variability and population genetics of numerous organisms (Xu et al., 2011). Different mtDNA gene sequences can be used to determine the variation in fish (Saraswat et al., 2014). Diversity in mtDNA cyt $b$ gene is suitable for population genetic studies in cyprinid fishes (Fayazi et al., 2006).
The aim of this research is to determine genetic diversity of A. grypus populations in Euphrates and Tigris rivers via sequence analysis for mtDNA Cyt $b$ fragment.

\section{Materials and Methods}

Collection offish samples: A total of 31 individuals (15 from Euphrates and 16 from Tigris River) were collected via fishing method. $2 \mathrm{~g}$ of specimen was dissected from muscle tissue on the base of pectoral or dorsal fins of fish samples, held in refrigerator at $4{ }^{\circ} \mathrm{C}$ inside micro centrifuge tubes with $1.5 \mathrm{~mL}$ volume, containing $95 \%$ ethanol until DNA isolation process.

DNA isolation: Total DNA was isolated from muscular tissue using GeneJET Genomic DNA Purification Kit (Thermo Scientific). Total DNA was obtained by practiced the protocol for the kit. To control the existence of DNA, 2 $\mu \mathrm{l}$ was taken from DNA samples of each individual, placed in to tank including $0.8 \%$ agarose gel, $0.5 \mathrm{xTBE}$ (Tris/Boric acid/EDTA Buffer) solution with the addition of $2 \mu \mathrm{l}$ of stain (3x Loading dye) and SYBR Green, run in electrophoresis at 120 Volts for 30 minutes, then viewed in device giving off ultraviolet (UV) light (SmartView Pro Imager System, Major Science).

Amplification of target mtDNA site via polymerase chain reaction (PCR): Primers used for amplification of mtDNA Cytochrome b gene in the study (Briolay et al., 1998) were given below:

\section{L15267: 5'-AATGACTTGAAGAACCACCGT-3' \\ H15891: 5'-GTTTGATCCCGTTTCGTGTA-3'}

The PCR amplification process was carried out in a BIORAD T $100^{\mathrm{TM}}$ Thermal Cycler under the following conditions: 3 minute at $95^{\circ} \mathrm{C}$ for initial denaturation and $30 \mathrm{sec}-$ onds at $95^{\circ} \mathrm{C}$ for the second denaturation, 30 seconds at $58^{\circ} \mathrm{C}$ for annealing, 45 seconds at $72^{\circ} \mathrm{C}$ for extension, 35 cycles in total and a final extension at $72^{\circ} \mathrm{C}$ for 10 minutes. The amounts of DNA, concentrations of chemicals, and annealing temperatures of primes used in PCR amplification reactions were optimized by gradient PCR device. PCR mixture used in order to amplify this gene is as follows; a total volume of $25 \mu \mathrm{L}$ containing $0.5 \mathrm{mM}$ of each primer, $0.2 \mathrm{mM}$ of each dNTP, $1 \times$ PCR buffer, $2.5 \mathrm{mM} \mathrm{MgCl}_{2}, 1$ unit Taq polymerase and approximately $60 \mathrm{ng}$ of template DNA.

$2 \%$ agarose gel was used to control final products of PCR process. Agarose gel which was included SYBR Green was run at $100 \mathrm{~V}$ electric current for 30 after placing in a tank with $0.5 x$ TBE solution and loading $2 \mu$ of PCR product and 
$2 \mu \mathrm{L}$ of stain in to wells, then monitored under UV device. (Figure 1).

Obtained PCR products were analyzed via 3500 XL Genetic Analyser (Thermo Fisher Scientific) by a commercial company.

Analysis of mtDNA cyt $b$ sequences: Raw data of mtDNA sequences, which were delivered to us by commercial company, were evaluated and converted in to FASTA format by using Chromas Pro v 2.0.1 (Technelysium Pty Ltd). Resulting sequences in FASTA format were aligned utilizing BioEdit software version 7.2.5 program.

The number of polymorphic sites and haplotypes, diversity of haplotypes and nucleotides, Tajima D and Fu's statistics for the populations were identified by using DnaSP5.10.01 program (Rozas et al., 2003). The phylogenetic relationship between haplotypes was identified via Network version 5.0 program.

\section{Results and Discussion}

Genetic variation: Approximately $600 \mathrm{bp}$ fragment of mtDNA Cytochrome $b$ gene was sequenced from a total of 31 A. grypus samples in Euphrates and Tigris Rivers, 5 polymorphic sites and 5 haplotypes were identified. Nucleotide variations of this region were shown in Table 1.

Haplotype diversity $(\mathrm{Hd})$ and nucleotide diversity $(\pi)$ for each locality were given in Table 2 .

In Table 2, H1 is the haplotype which has the highest frequency commonly seen in all localities. Haplotype $\mathrm{H} 2$ was observed only in Bozova locality, H3 in both Çermik and Dicle locality, haplotypes H4 and H5 in Dicle locality only. While Siverek locality had the lowest values in terms of both haplotype and nucleotide diversity, other localities had similar results. The locality with the highest nucleotide diversity is Bozova.

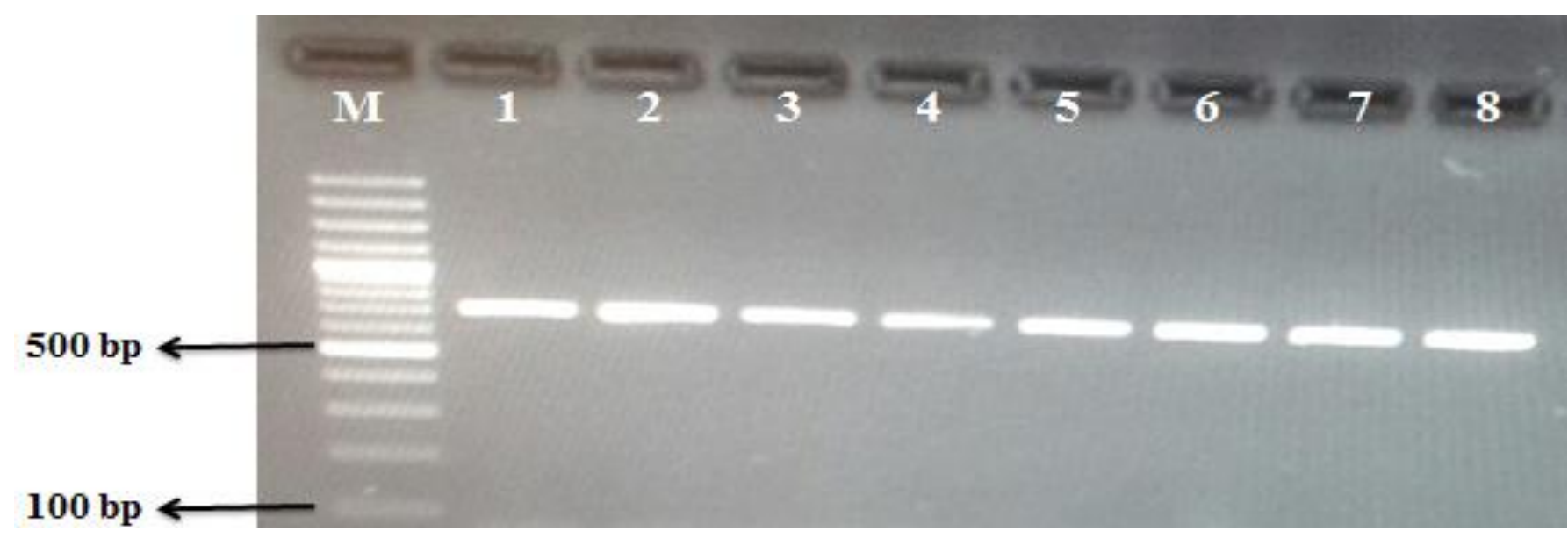

Figure 1. Image of PCR Products (M: Marker; bp: base pairs)

Table 1. Haplotypes and nucleotide variations of mtDNA Cytochrome b gene

\begin{tabular}{cccccc}
\hline Haplotypes & 291 & $\mathbf{3 4 0}$ & $\mathbf{4 1 7}$ & $\mathbf{4 5 3}$ & $\mathbf{4 7 1}$ \\
\hline H1 & G & T & G & C & G \\
H2 & A & C & $\cdot$ & $\cdot$ & A \\
H3 & A & C & $\cdot$ & $\cdot$ &. \\
H4 &. &. &. & T & $\cdot$ \\
H5 &. &. & A &. &. \\
\hline
\end{tabular}


Table 2. Genetic diversity of A.grypus localities based on mtDNA cytochrome b gene sequence and neutrality tests $(\mathrm{N}=$ number of individuals, Nh: number of haplotypes, Hd: haplotype diversity, $\pi$ : nucleotide diversity)

\begin{tabular}{|c|c|c|c|c|c|c|}
\hline River System & Locality & $\mathbf{N}$ & Nh & $\begin{array}{l}\text { Haplotype } \\
\text { frequency }\end{array}$ & Hd & $\pi$ \\
\hline Euphrates River & Siverek & 5 & 1 & H1 (1.0000) & 0.000 & 0.00000 \\
\hline \multirow[t]{2}{*}{ Euphrates River } & Bozova & 5 & 2 & H1 (0.8000) & 0.400 & 0.00194 \\
\hline & & & & $\mathrm{H} 2(0.2000)$ & & \\
\hline \multirow[t]{2}{*}{ Euphrates River } & Çermik & 5 & 2 & H1 (0.8000) & 0.400 & 0.00175 \\
\hline & & & & H3 (0.2000) & & \\
\hline \multirow[t]{4}{*}{ Tigris River } & Dicle & 16 & 4 & H1 (0.7500) & 0.442 & 0.00135 \\
\hline & & & & H3 (0.1250) & & \\
\hline & & & & H4 (0.0625) & & \\
\hline & & & & H5 (0.0625) & & \\
\hline
\end{tabular}

In Table 2, H1 is the haplotype which has the highest frequency commonly seen in all localities. Haplotype $\mathrm{H} 2$ was observed only in Bozova locality, $\mathrm{H} 3$ in both Çermik and Dicle locality, haplotypes H4 and H5 in Dicle locality only. While Siverek locality had the lowest values in terms of both haplotype and nucleotide diversity, other localities had similar results. The locality with the highest nucleotide diversity is Bozova.

In Median-Joining Network created for 31 A. grypus samples analyzed 5 haplotypes were identified in total, resulting network includes existence of a central haplotype (H1) indicating an evolutionary connection. It is also likely to say that all other haplotypes are associated with haplotype H1 (Figure 2).

Neutrality tests: Neutrality tests (Tajima's D and Fu's Fs) were applied separately for each river. Tajima's D statistic was -0.94808 for Euphrates river and -1.26856 for Tigris river, -1.28294 in total, and found to be statistically insignificant ( $p>0.05)$. Fu' Fs values were determined as -0.006 for Euphrates river and -0.993 for Tigris river, -1.28294 in total, and found to be statistically insignificant ( $\mathrm{p}>0.05)$.
In the present study, genetic diversity of populations was evaluated by conducting sequence analysis of approximately $600 \mathrm{bp}$ of mtDNA cyt b. five polymorphic sites and five haplotypes were identified for this gene analyzed. Considering the fact that haplotype $\mathrm{H} 1$ was the most prevalent one with totally 25 individuals including 3 haplotypes (H1, $\mathrm{H} 2, \mathrm{H} 3)$ in the Euphrates, 4 (H1, H3, H4, H5) in the Tigris, therefore it is possible to speculate that Haplotype H1 was ancestral because it was common in all populations. Even though haplotypes $\mathrm{H} 1$ and $\mathrm{H} 3$ were commonly seen in both river systems, haplotype $\mathrm{H} 2$ was observed only in the Euphrates, haplotypes $\mathrm{H} 4$ and $\mathrm{H} 5$ in only in individuals from the Tigris. Mean haplotype diversity (Hd) and nucleotide diversity $(\pi)$ were calculated to be 0.442 and 0.00152 for individuals from Tigris River; 0.257 and 0.00138 for individuals from Euphrates River, respectively. Both values of Tigris River were higher. Therefore, it can be suggested to collect samples from Tigris River for the studies on aquaculture of this species. Mean haplotype diversity $(\mathrm{Hd})$ and nucleotide diversity $(\pi)$ were calculated to be 0.348 and 0.00144 for all of the individuals, respectively. Parmaksiz et al., (2017) identified in their study on mtDNA COI gene of A. grypus that haplotype diversity and nucleotide diversity were 0.246 and 0.00045 ; respectively. The results in the present study were higher. Haplotype diversity was 0.642 
and nucleotide diversity was 0.00138 in the study by Parmaksız and Eksi (2017) conducted for mtDNA COI gene in Capoetta trutta populations inhabiting in the same river systems, while nucleotide diversity was similar compared to the present survey, haplotype diversity was higher. Environmental heterogeny and population size may support protection of high population diversity in populations (Nei, 1987; Avise, 1998). Haplotype diversity of A. grypus species was found to be lower because the number of individuals decreased thanks to overhunting.

This fish species is caught by fishermen and local people because all of the localities where samples of our research were collected are near to residential areas. The fish caught are both consumed by locals and sold to neighboring provinces. Genetic diversity of $A$. grypus populations has been decreasing due to overhunting.

Median joining network analysis revealed that haplotype $\mathrm{H} 1$ was at the center of network and dominant, also all other haplotypes consisted of haplotype $\mathrm{H} 1$ indicating it was the ancestral one.

Some haplotypes identified in the present study possess new results for mtDNA cyt $b$ gene, created an important data set for genetic diversity of this species. (Table 3 ).

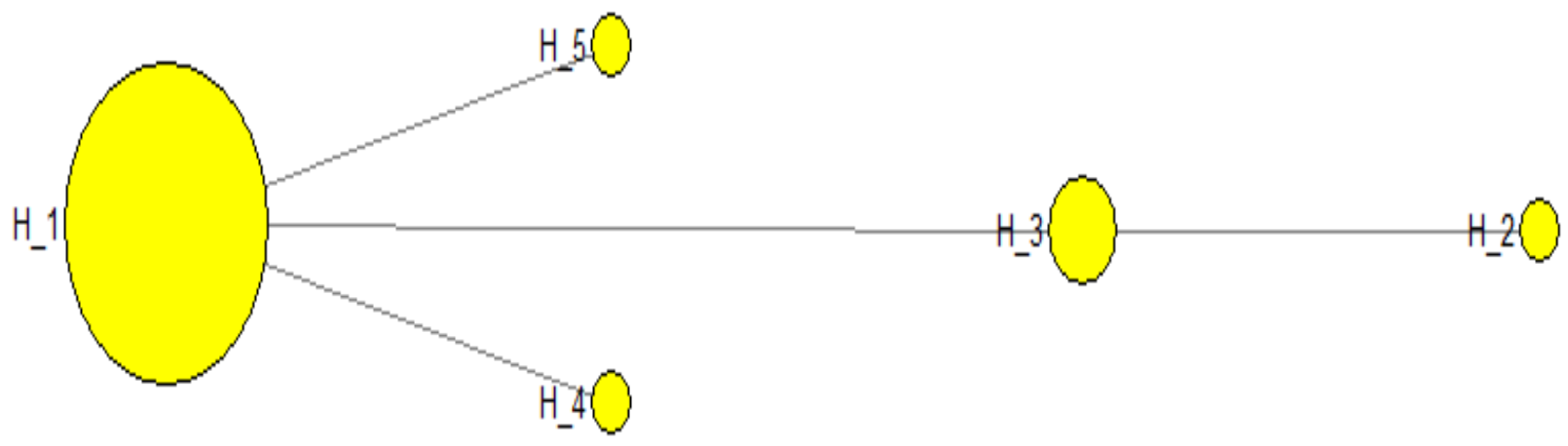

Figure 2. The model of A. grypus cyt b haplotypes

Table 3. Total cyt b haplotypes of A. grypus in the present study and GenBank

\begin{tabular}{|l|l|}
\hline Haplotype & GenBank Data \\
\hline H1 & This study and KF876028, KF876027, AF145945 \\
\hline H2 & This study \\
\hline H3 & This study and KF876026 \\
\hline H4 & This study \\
\hline H5 & This study \\
\hline
\end{tabular}




\section{Conclusions}

This species is endemic and the most economically important species in the region. The population of this species have been influenced by pollution, destruction of habitat and especially over fishing exploitation. In this study, the sampling localities were only four localities. Further study based on microsatellite markers and mtDNA marker (D-loop) a comprehensive sampling collection is needed to extend for genetic diversity.

\section{Acknowledgements}

This study was funded by Harran University Research Fund (Project No: 16200). The authors report no conflicts of interest.

\section{References}

Abdoli, A. (2000). The inlandwater fishes of Iran. Iranian Museum of Nature and Wildlife, Tehran. 378p. ISBN: 964-6902-01-4

Asefi, M., Zamani-Ahmadmahmoodi, R. (2015). Mercury concentrations and health risk assessment for two fish species, Barbus grypus and Barbus luteus, from the Maroon River, Khuzestan Province, Iran. Environmental Monitoring and Assessment, 187, 653.

Avise, J. (1998). Phylogeography. Cambridge: MA. Harvard University Press., 102 pp. ISBN: 9780674666382

Briolay, J., Nicols Galtier, N., Brito, R. M., Bouvet, Y. (1998). Molecular Phylogeny of Cyprinidae Inferred from cytochrome b DNA Sequences. Molecular Phylogenetics and Evolution, 9(1), 100-108.

Dogu, Z., Aral, F. Sahinoz, E. (2014). The determination of some spermatological and hematological parameters of shabbout (Barbus grypus) in Atatürk Dam Lake, Sanliurfa. Journal of FisheriesSciences.com, 8 8(4), 265277.

Dusukcan, M., Calta M., Eroglu, M. (2015). Keban Baraj Gölü'nde Yaşayan Barbus grypus Heckel, 1843'de Otolit Biyometrisi-Balık Boyu İlişkisi. Yunus Araştırma Bülteni, 3, 21-29.

Fayazi, J., Moradi, M., Rahimi, G., Ashtyani, R., Galledari, H. (2006). Genetic differentiation and phylogenetic relationships among Barbus xanthopterus (Cyprinidae) populations in south west of Iran using mitochondrial
DNA markers. Pakistan Journal of Biological Science, 9, 2249-54.

Gokcinar, N.C. (2010). Effect of partially replacing fishmeal with azolla (Azolla sp.) on growht parametres of shabbout fish (Tor grypus H. 1843). MSc thesis, Ankara University, Turkey. 51p.

Kaya, C. (2012). The fish fauna of the upper basin of the Tigris River, MSc thesis, Recep Tayyip Erdoğan University, Turkey. 156p.

Khodadadi, M., Arab, A., Jaferian, A. (2016). A Preliminary Study on Sperm Morphology, Motility and Composition of Seminal Plasma of Shirbot, Barbus grypus. Turkish Journal of Fisheries and Aquatic Sciences, 16, 947-951.

Liu, G., Zhou, L. (2016). Population genetic structure and molecular diversity of the red swamp crayfish in China based on mtDNA COI gene sequences, Mitochondrial DNA Part A, 28 (6), 860-866.

Mohammadian T., Alishahi, M., Tabandeh, M.R., Ghorbanpoor, M., Gharibi, D., Tollabi, M., Rohanizade, S. (2016). Probiotic effects of Lactobacillus plantarum and L. delbrueckii ssp. bulguricus on some immune-related parameters in Barbus grypus. Aquaculture International, 24, 225-242.

Nei, M. (1987). Molecular evolutionary genetics. New York: Columbia University Press., 512 pp. ISBN: 9780231063210

Nikpei, M. (1996). Research project report: biological study of Barbus grypus and Barbus sharpie. Iranian Fisheries Research Institute, 1, 52-64.

Oymak, S. A., Dogan, N., Uysal, E. (2008). Age, growth and reproduction of the Shabut Tor grypus (Cyprinidae) in Ataturk Dam Lake (Euphrates River), Turkey. Cybium, 32, 2, 145-152.

Oymak, S. A., Karadede, H., Dogan, N. (2009). Heavy metal in tissues of Tor grypus from Ataturk Dam Lake, Euphrates River-Turkey, Biologia, 64, 1, 151-155.

Parmaksı, A., Ates, B., Toprak, S. (2016). Investigation of usefulness of DNA Microsatellite markers in some carp 
species. Harran Üniversitesi Veteriner Fakültesi Dergisi, 5(1), 1-4.

Parmaksiz, A., Seker, O., Aslan, N., Oymak, A. (2017). Determination of Genetic Diversity in Barbus grypus Heckel, 1843 Populations by mtDNA COI Gene Sequences. Yunus Araştırma Bülteni, 1, 103-107.

Parmaksız, A., Eksi, E. (2017). Genetic diversity of the cyprinid fish Capoeta trutta (Heckel, 1843) populations from Euphrates and Tigris rivers in Turkey based on mtDNA COI sequences. Indian Journal of Fisheries, 64(1), 18-22.

Rozas, J., Sanchez- DelBarrio, J. C., Messeguer, X. Rozas, R. (2003). DnaSP DNA polymorphism analyses by the coalescent and other methods. Bioinformatics, 19, 2496-2497.

Saraswat, D., Lakra, W.S., Nautiyal, P., Goswami, M., Shyamakant, K., Malakar, A. (2014). Genetic characterization of Clupisoma garua (Hamilton 1822) from six Indian populations using mtDNA cytochrome $b$ gene. Mitochondrial DNA, 25(1), 70-77.

Xu, Z.H., Chen, J.L., Cheng, D.F., Liu, Y., Eric, F. (2011). Genetic variation among the geographic population of the Grain Aphid, Sitobion avenae (Hemiptera: Aphididae) in China inferred from mitochondrial COI gene sequence. Agricultural Sciences in China, 10, 10411048. 